\title{
Beta cell death in hyperglycaemic Psammomys obesus is not cytokine-mediated
}

\author{
A. Jörns • K. J. Rath • O. Bock • S. Lenzen
}

Received: 29 June 2006 / Accepted: 17 July 2006 / Published online: 20 September 2006

(C) Springer-Verlag 2006

\begin{abstract}
Aims/hypothesis It has recently been proposed that IL-1 $\beta$ may be responsible for beta cell death in type 2 diabetes mellitus. Major support for this assumption was derived from experiments in the gerbil Psammomys obesus (sand rat), a model for nutritionally induced non-insulin-dependent type 2 diabetes. Using gerbil-specific primers for the analysis of gene expression, we investigated the validity of this hypothesis.

Methods Gene expression was analysed by real-time RTPCR of isolated and laser-microdissected islets and by in situ RT-PCR, both in beta cells and in immune cells, as well as in lymph nodes and spleen.

Results We were unable to detect $I l-1 \beta$ and the IL- $1 \beta$ inducible enzyme inducible nitric oxide synthase (iNos) by in situ RT-PCR, either in the pancreatic beta cells, or in the small number of non-activated immune cells of healthy and diabetic Psammomys obesus after 1 and 3 weeks on a highenergy diet. Very low levels of $I l-1 \beta$ and $i N o s$ mRNA were detectable in collagenase-isolated and laser-microdissected islets of normoglycaemic gerbils by real-time RT-PCR
\end{abstract}

Electronic supplementary material Supplementary material is available in the online version of this article at http://dx.doi.org/ $10.1007 / \mathrm{s} 00125-006-0413-2$ and is accessible to authorised users.

A. Jörns $(\triangle)$

Centre of Anatomy and Institute of Clinical Biochemistry,

Hannover Medical School,

30625 Hannover, Germany

e-mail: joerns.anne@mh-hannover.de

K. J. Rath $\cdot$ S. Lenzen

Institute of Clinical Biochemistry, Hannover Medical School,

Hannover, Germany

O. Bock

Institute of Pathology, Hannover Medical School,

Hannover, Germany without any increase of these mRNAs in islets from diabetic animals. These results were confirmed by electron microscopy with immunogold staining for IL- $1 \beta$ and insulin. Conclusions/interpretation The diabetic syndrome induced in Psammomys obesus by high-energy diet is a classical type 2 diabetes model, which does not show any evidence of an involvement of the proinflammatory cytokine IL-1 $\beta$ or of activated immune cells in its pathogenesis. This is clearly at variance with the situation in type 1 diabetes.

Keywords Beta cell death · Cytokine expression · IL-1 $\beta$. Pancreatic beta cells P Psammomys obesus .

Type 2 diabetes mellitus

\section{Abbreviations \\ ESM Electronic supplementary material \\ iNOS inducible nitric oxide synthase}

\section{Introduction}

It is generally accepted that cytokines play a crucial role in the pathogenesis of type 1 diabetes mellitus [1-3]. Recently it has been proposed that cytokines may also be involved in the aetiopathology of beta cell death in type 2 diabetes mellitus [4-7]. Major support for this hypothesis was derived from experiments on the gerbil Psammomys obesus (sand rat) [8, 9], an established type 2 diabetes animal model $[10,11]$. When fed a high-energy diet, these animals develop a diabetic syndrome $[10,11]$.

It was reported some years ago that pancreatic beta cells from this type 2 diabetes animal model exhibited immunohistochemical staining for IL- $1 \beta$, when after 1 week on a highcarbohydrate diet diabetic hyperglycaemia had developed [8]. 
More recently the authors endorsed this observation and in addition demonstrated IL-1 $\beta$ gene and protein expression in isolated islets from human type 2 diabetic donors, as well as in islets from healthy human donors incubated for 3 days at $30 \mathrm{mmol} / \mathrm{l}$ glucose $[6,9]$. On the basis of these observations, the authors proposed that the proinflammatory cytokine IL$1 \beta$ also plays a prominent role in pancreatic beta cell loss in type 2 diabetes mellitus [4, 6, 9]. However, other authors were not able to confirm these observations. Thus both immunohistochemical staining of beta cells from diabetic Psammomys obesus [12], and analyses of the expression of the gene encoding IL- $1 \beta$ in islets isolated from healthy and type 2 diabetic human pancreas donors [13] failed to show an increase of the very low basal $I l-1 \beta$ expression level in the beta cells in response to high glucose.

Species differences in the specificity of antibodies and of primers may affect the detection of IL- $1 \beta$ in beta cells of the gerbil Psammomys obesus. Therefore, in order to provide conclusive experimental evidence on this crucial question, we used for the first time gerbil-specific primers to analyse the expression of the genes encoding IL-1 $\beta$ and other proinflammatory cytokines, as well as of the IL- $1 \beta$-inducible enzyme inducible nitric oxide synthase (iNOS). We performed real-time RT-PCR of isolated and laser-microdissected islets and in situ RT-PCR both on beta cells and immune cells in the pancreatic islets. As positive controls, the pancreas-draining lymph nodes and the spleen of healthy and diabetic Psammomys obesus were examined in parallel.

\section{Materials and methods}

Animals

We used 12- to 14-week-old Psammomys obesus (sand rat) from the DP line $[10,11]$ from the colony maintained at the Animal Facility of the Hebrew University-Hadassah Medical School, Jerusalem (kindly provided by E. Shafrir). These animals were fed either on a low-energy diet (2.38 kcal/g; Koffolk, Petach, Tikva, Israel) or on a highenergy diet $(2.93 \mathrm{kcal} / \mathrm{g}$; Weizmann Institute, Rehovot, Israel) for 1 or 3 weeks [14]. All sand rats were maintained according to the Federation of European Laboratory Animal Science Associations guidelines. The animal experiments were carried out according to the specific national laws of Germany, under a license for animal experimentation granted by the local government of Hanover to S. Lenzen.

\section{Tissue processing}

For light microscopy, tissue specimens of pancreas, pancreas-draining lymph nodes, and spleen were fixed in $4 \%$ paraformaldehyde in $0.15 \mathrm{~mol} / 1 \mathrm{PBS}, \mathrm{pH} 7.3$, or rapidly frozen in liquid nitrogen [14]. Fixed tissue was embedded in paraffin and frozen tissue was stored at $-70^{\circ} \mathrm{C}$ either for RNA isolation or for cryostat histology. For electron microscopy, pieces of pancreas were fixed in $2 \%$ paraformaldehyde and $2 \%$ glutaraldehyde, in $0.1 \mathrm{~mol} / 1$ cacodylate buffer, $\mathrm{pH} 7.3$, postfixed in $1 \% \mathrm{OsO}_{4}$ and finally embedded in epoxy resin [14]. Thin sections were contrast-stained with saturated solutions of lead citrate and uranyl acetate.

Immunogold staining

Thin sections were stained using the post-embedding method of immunogold for insulin (1:200-1:500; A565; DAKO, Hamburg, Germany) and IL-1 $\beta$ (1:50-1:400; Serotec, Oxford, UK) to localise these proteins by electron microscopy (EM 10; Zeiss, Oberkochem, Germany) in the subcellular compartments of pancreatic beta cells and immune cells [15].

\section{In situ RT-PCR}

Sections from the pancreas and other organs on 3-chamber slides (SuperFrost Plus; MJ Research, Waltham, MA, USA) were treated for in situ RT-PCR gene expression analysis using a thermal cycler suitable for in situ amplifications (PTC-200 Twin Tower DNA Engine; MJ Research, Waltham, MA, USA) as described in detail elsewhere [16]. After both digestion steps with proteinase $\mathrm{K}$ and with an RNase-free DNase solution, a two step protocol with reverse transcription and PCR amplification was used. Thereafter the incorporated digoxigenin-labelled nucleotides were detected by an anti-digoxigenin antibody labelled with alkaline phosphatase (1:500) for $1 \mathrm{~h}$. Alkaline phosphatase activity was detected by the nitro blue tetrazolium chloride/5-bromo-4-chloro-3-indolyl phosphate toluidine salt colour reaction $(2 \mathrm{~h}$ incubation at room temperature). In our study we used gerbil-specific primers to exclude the existing species differences in the gene sequences of $I l-1 \beta$ and other cytokines, as well as of $i N o s$ between gerbil (Gene Bank No: AB069972) and rat (Gene Bank No: M98820) as a potential reason for false positive results. The specific gerbil primer sequences for in situ and real-time RT-PCR are given in the Electronic Supplementary Material (ESM Table 1). The amplicon size was between 80 and $133 \mathrm{bp}$ for real-time and between 342 and $503 \mathrm{bp}$ for in situ RT-PCR. In addition a rat insulin primer was used to detect the expression of the gene encoding insulin in pancreatic beta cells in Psammomys obesus [16].

Laser-assisted microdissection

Pancreatic sections (4- $\mu \mathrm{m}$ thick) were mounted on to polyethylene foil-covered slides, stained with methylene blue and dried at $37^{\circ} \mathrm{C}$ for $4 \mathrm{~h}$. For islet-specific 

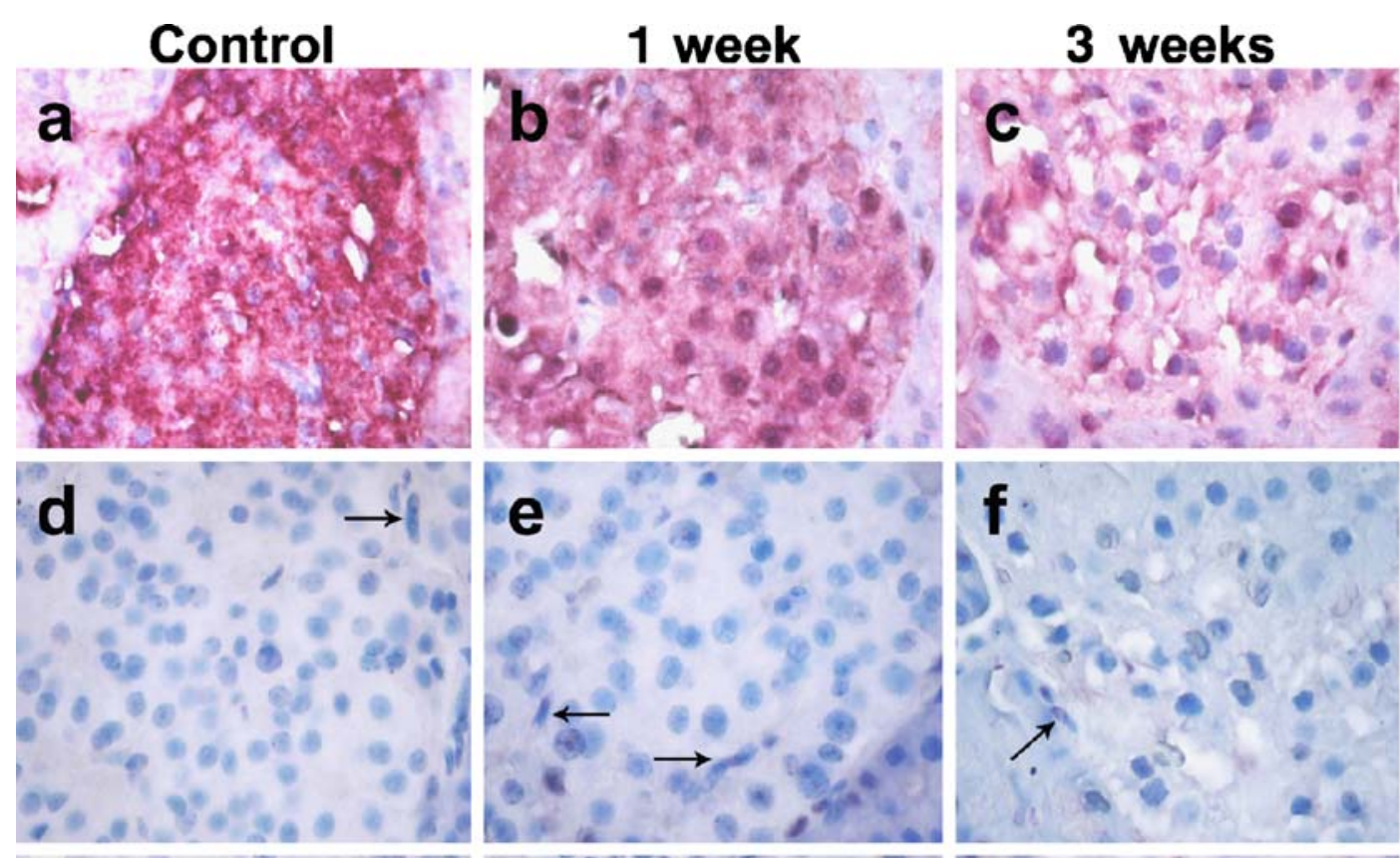

\section{Islet insulin}
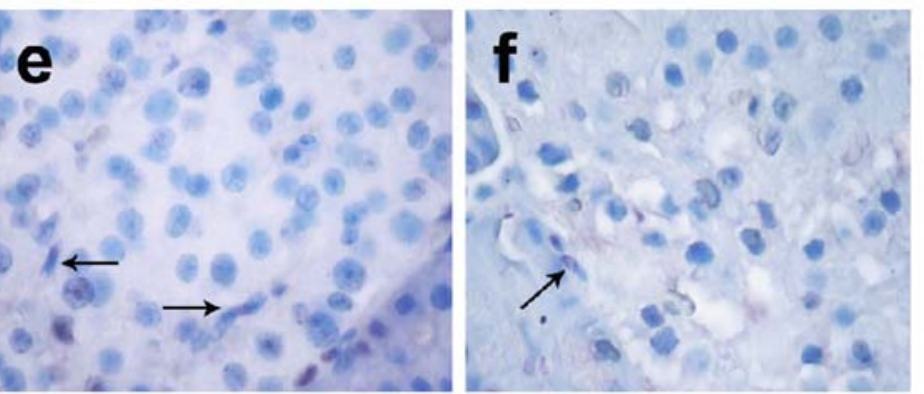

\section{Islets \\ // -1ß}
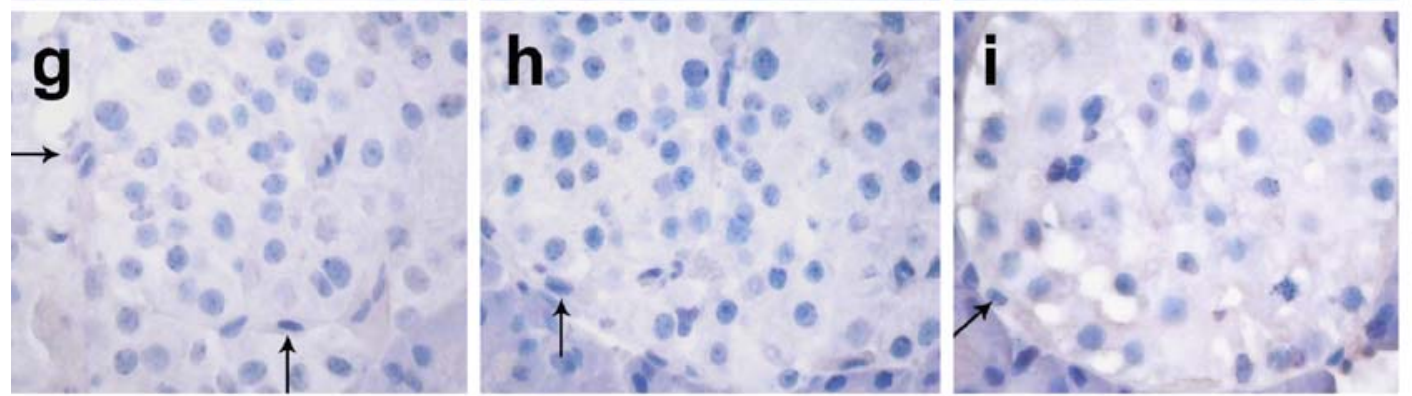

Islet
iNos
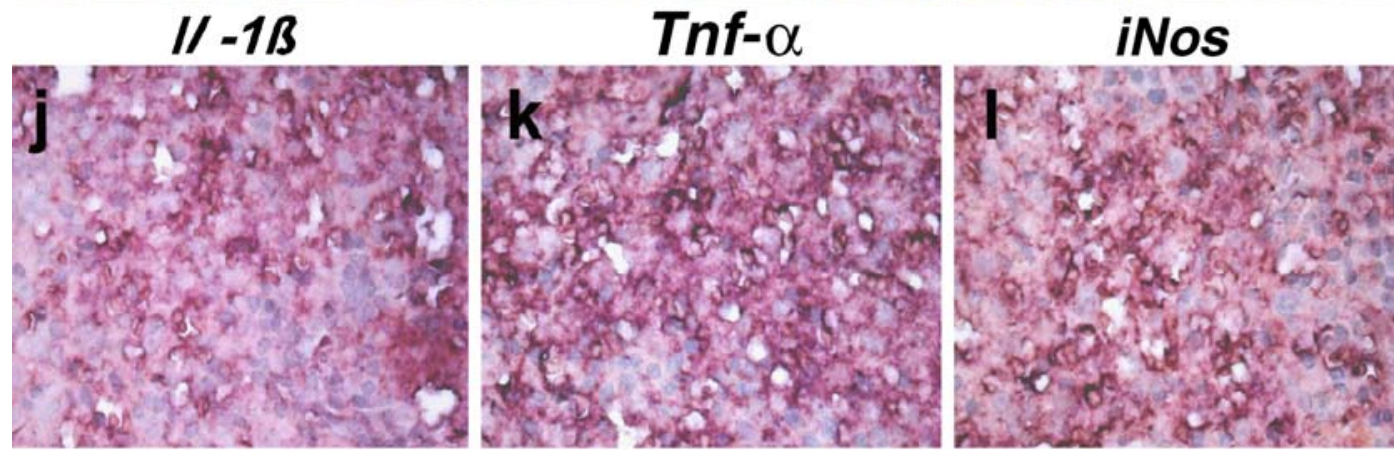

\section{Spleen \\ 3 weeks}
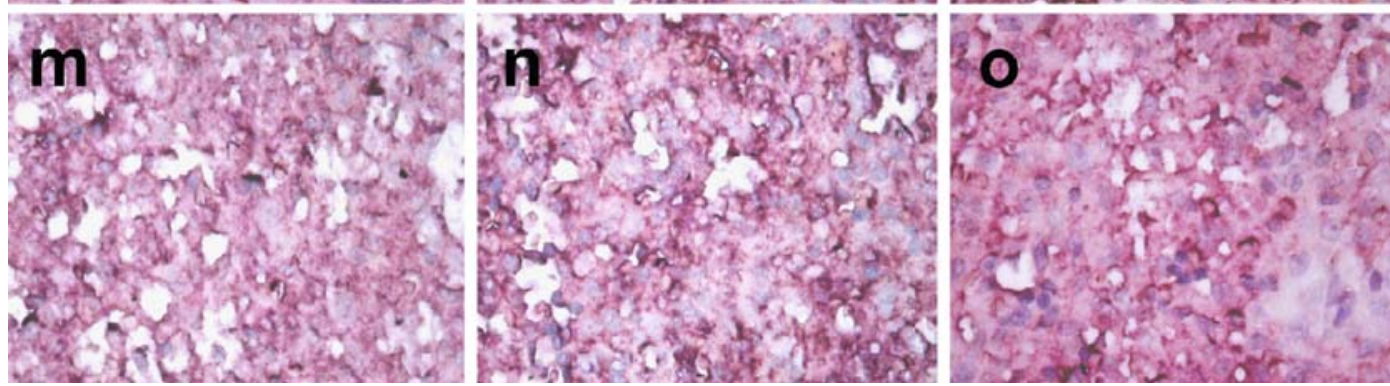

\section{Lymph node 3 weeks}

Fig. 1 Expression, as determined by in situ RT-PCR, of the following genes: insulin $(\mathbf{a}-\mathbf{c}), I l-1 \beta(\mathbf{d}-\mathbf{f}, \mathbf{j}, \mathbf{m}), i N o s(\mathbf{g}-\mathbf{i}, \mathbf{l}, \mathbf{o})$ and $\operatorname{Tnf}-\alpha(\mathbf{k}, \mathbf{n})$ in the pancreatic islets $(\mathbf{a}-\mathbf{i})$, in the spleen $(\mathbf{j}-\mathbf{l})$ and pancreas-draining lymph nodes ( $\mathbf{m}-\mathbf{0})$ of sand rats as indicated (control, 1 , and 3 weeks after high-energy diet). The pancreatic beta cells revealed a decrease in insulin mRNA expression during diabetes development $(\mathbf{a}-\mathbf{c})$. In comparison with the islets $(\mathbf{d}-\mathbf{i})$, which expressed neither $I l-1 \beta$ nor $i$ Nos transcripts, the immune cells in the lymphoid tissue showed mRNA expression of $I l-1 \beta(\mathbf{j}, \mathbf{m}), \operatorname{Tnf}-\alpha(\mathbf{k}, \mathbf{n})$ and $i N o s(\mathbf{l}, \mathbf{o})$. Arrows, immune cells in the islets $(\mathbf{d}-\mathbf{i})$. Magnification $\times 400$ 
proinflammatory cytokine expression as well as for iNOS expression, a laser microdissection microscope (PALM Laser Micro Beam System; P.A.L.M., Bernried, Germany) was used to isolate the islets from the surrounding exocrine pancreatic tissue by focused nitrogen laser beam under direct visual control [17]. Microdissected islets were then directly catapulted by a single laser shot into the lid of a microfuge tube. Per animal, 80 to 120 islets were collected from serial pancreatic tissue sections. RNA was extracted from the microdissected tissue samples as described previously [18].

\section{Real-time RT-PCR}

The mRNA from either frozen pancreases or microdissected islets of 7- or 21-day-old diabetic sand rats and normoglycaemic control animals was reverse transcribed using oligo dT primer. Expression of selected genes was quantified using QuantiTect SYBR Green technology (Qiagen, Hilden, Germany), which uses a fluorescent dye that binds only double-stranded DNA. The reactions were performed using the microplate-based DNA Engine Opticon fluorescence detection system (MJ Research) as described previously [19]. A total volume of $25 \mu \mathrm{l}$ was used for the PCR reactions. Samples were first denatured at $94^{\circ} \mathrm{C}$ for $2 \mathrm{~min}$ followed by up to 40 PCR cycles. Each PCR cycle comprised a denaturation at $94^{\circ} \mathrm{C}$ for $30 \mathrm{~s}$, an annealing at 62 to $65^{\circ} \mathrm{C}$ for $30 \mathrm{~s}$, and an extension at $72^{\circ} \mathrm{C}$ for $30 \mathrm{~s}$. Each PCR amplification was performed in triplicate. The optimal parameters for the PCR reactions were empirically defined. The purity of the amplified PCR products was verified by melting curves. $\beta$-Actin was used as the reference gene. Real-time RT-PCR analyses were performed for $I l-1 \beta$, Ifn- $\gamma, \operatorname{Tnf}-\alpha$, and iNos. The sequences of the forward and reverse primers for the real-time RTPCR were mostly located in the regions inside those of in situ PCR primers.

\section{Statistical analyses}

Data are expressed as means \pm SEM. Statistical analyses were performed by Student's $t$ test using the Prism analysis program (Graphpad, San Diego, CA, USA).

\section{Results}

Expression of the genes encoding proinflammatory cytokines and iNOS as determined by in situ RT-PCR in Psammomys obesus

Pancreatic beta cells in Psammomys obesus on a highenergy diet for 1 (Fig. 1b) or 3 (Fig. 1b) weeks showed a typical decrease in expression of the gene encoding insulin during diabetes development, as compared with normoglycaemic controls (Fig. 1a). This decrease was accompanied by the gradual and morphometrically documented loss of insulin immunoreactivity in the pancreatic beta cells after 1 to 3 weeks on the high-energy diet [14]. The decreased expression of the gene encoding insulin during development of hyperglycaemia was also accompanied by the appearance of intracellular vacuoles as signs of diabetic beta cell damage (Fig. 1b,c).

The gene encoding the proinflammatory cytokine IL-1 $\beta$ was undetectable both in the pancreatic beta cells of healthy (Fig. 1d), and in those of diabetic Psammomys obesus after 1 (Fig. 1e) and 3 (Fig. 1f) weeks on a high-energy diet. The proinflammatory cytokines IFN- $\gamma$ and TNF- $\alpha$ were also undetectable (data not shown), as was mRNA expression of the IL- $1 \beta$-inducible enzyme $i$ Nos in pancreatic beta cells of healthy (Fig. 1g) and diabetic Psammomys obesus after 1 (Fig. 1h) and 3 (Fig. 1i) weeks on a high-energy diet. In the small numbers of immune cells, mostly macrophages and a few neutrophils, within and around the islets in the pancreas both of healthy (Fig. 1d,g) and of diabetic Psammomys obesus after 1 (Fig. 1e,h) and 3 (Fig. 1f,i) weeks on a highenergy diet, we did not detect any expression of the genes encoding IL- $1 \beta$ or iNOS.

In control experiments, mRNA expression of $I l-1 \beta$ (Fig. 1j,m), Ifn- $\gamma$ (data not depicted), Tnf- $\alpha$ (Fig. 1k,n) and $i N o s$ (Fig. 11,o) was clearly visible in the immune cells of the spleen (Fig. 1j-1) and pancreas-draining lymph nodes (Fig. 1m-o), confirming that the gerbil-specific primers used in this study specifically detected the mRNA transcripts of these genes in the cytoplasm.

Evaluation of expression of genes encoding proinflammatory cytokines and iNOS by real-time RT-PCR in Psammomys obesus

Both collagenase-isolated islets (Table 1) and laser-microdissected islets (Table 2) from control and diabetic Psammomys obesus were used for real-time RT-PCR to detect the proinflammatory cytokines and iNOS. Expression of $I l-1 \beta$ was detectable at a very low level in collagenase-isolated (Table 1) and laser-microdissected islets (Table 2) of normoglycaemic control animals. In collagenase-isolated islets (Table 1) after 1 week on a highenergy diet (Table 1) and in laser-microdissected islets after 1 and 3 weeks on a high-energy diet (Table 2) no visible increase in the expression of $I l-1 \beta$ could be seen. If anything, expression of this gene was decreased, in line with beta cell destruction during hyperglycaemia-induced diabetic damage (Tables 1 and 2).

The expression of the genes encoding the proinflammatory cytokines IFN- $\gamma$ and TNF- $\alpha$ was so low in pancreatic 
Table 1 Relative gene expression of Il-1 $\beta$, Tnf- $\alpha$, Ifn- $\gamma$ and $i N o s$ in collagenase-isolated pancreatic islets from control and diabetic Psammomys obesus

Collagenase-isolated islets

\begin{tabular}{lll}
\hline $\begin{array}{l}\text { Relative expression } \\
\left(\times 10^{3}\right)\end{array}$ & Control & $\begin{array}{l}\text { Diabetic after 1 week on } \\
\text { high-energy diet }\end{array}$ \\
Il- $1 \beta$ & $1.840 \pm 0.360$ & $0.670 \pm 0.086$ \\
Ifn- $\gamma$ & $0.024 \pm 0.008$ & $0.007 \pm 0.005$ \\
Tnf- $\alpha$ & $0.135 \pm 0.042$ & $0.062 \pm 0.017^{*}$ \\
iNos & $0.182 \pm 0.049$ & $0.075 \pm 0.019^{*}$ \\
Blood glucose & $5.6 \pm 0.1$ & $14.5 \pm 0.3^{*}$ \\
$(\mathrm{mmol} / \mathrm{l})$ & & \\
\hline
\end{tabular}

Real-time RT-PCR was performed with gerbil-specific primers for Il-1 $\beta$, Tnf- $\alpha$, Ifn- $\gamma, i N o s$ and $\beta$-Actin. Relative expression levels of the specific proinflammatory cytokines and iNos normalised to the housekeeping gene $\beta$-Actin and multiplied by $10^{3}$ are shown. Data are means \pm SEM from three individual experiments. ${ }^{*} p<0.05$ compared with control (Student's $t$ test)

islets of Psammomys obesus that mRNA transcripts were barely detectable in collagenase-isolated islets, even by highly sensitive real-time RT-PCR analysis (Table 1). In laser-microdissected islets expression of these genes was not detectable (Table 2). Again, as with IL-1 $\beta$, no stimulatory effect of hyperglycaemia on gene expression was seen (Tables 1 and 2).

The mRNA expression of the IL- $1 \beta$-inducible enzyme iNos was detectable in collagenase-isolated islets (Table 1) and laser-microdissected islets (Table 2) of normoglycaemic Psammomys obesus. No increase in expression of

Table 2 Relative gene expression of Il-1 $\beta$, Tnf- $\alpha$, Ifn- $\gamma$ and $i N o s$ in laser-microdissected pancreatic islets from control and diabetic Psammomys obesus

\begin{tabular}{|c|c|c|c|}
\hline \multirow[b]{2}{*}{$\begin{array}{l}\text { Relative } \\
\text { expression } \\
\left(\times 10^{3}\right)\end{array}$} & \multicolumn{3}{|c|}{ Laser-microdissected islets } \\
\hline & Control & $\begin{array}{l}\text { Diabetic after } \\
1 \text { week on high- } \\
\text { energy diet }\end{array}$ & $\begin{array}{l}\text { Diabetic after } \\
3 \text { weeks on high- } \\
\text { energy diet }\end{array}$ \\
\hline$I l-1 \beta$ & $0.081 \pm 0.051$ & $0.046 \pm 0.028$ & $0.082 \pm 0.027$ \\
\hline$I f n-\gamma$ & n. d. & n. d. & n. d. \\
\hline $\operatorname{Tnf}-\alpha$ & n. d. & n. d. & n. d. \\
\hline$i N o s$ & $0.087 \pm 0.025$ & $0.001 \pm 0.001 *$ & $0.028 \pm 0.016^{*}$ \\
\hline $\begin{array}{l}\text { Blood } \\
\text { glucose } \\
(\mathrm{mmol} / \mathrm{l})\end{array}$ & $5.7 \pm 0.1$ & $17.6 \pm 0.8^{*}$ & $22.3 \pm 0.6^{*}$ \\
\hline
\end{tabular}

Real-time RT-PCR was performed with gerbil-specific primers for Il-1 $\beta$, Tnf- $\alpha$, Ifn- $\gamma, i N o s$ and $\beta$-Actin. Relative expression levels of the specific proinflammatory cytokines Il-1 $\beta, T n f-\alpha$, and Ifn- $\gamma$ and of $i N o s$, multiplied by $10^{3}$ and normalised to the housekeeping gene $\beta$-Actin, are shown. Tnf- $\alpha$ and Ifn- $\gamma$ mRNA was not detectable (n.d.) because the cycle threshold values were in the range over 35 to 36 correlating to the background. Data are means \pm SEM from four to six individual experiments. ${ }^{*} p<0.05$ compared with control (Student's $t$-test)
iNos was seen after high-energy diet; if anything, expression of this gene decreased (Tables 1 and 2).

Ultrastructure of immune cells in pancreatic islets of Psammomys obesus

The islets of Langerhans from the Psammomys obesus showed all endocrine cell types as identified by their secretory granule morphology (Fig. 2). Compared with controls, the pancreatic beta cells showed decreased granulation after 1 and 3 weeks on the high-energy diet (Fig. 2) as described previously [14].

Gradually, the pancreatic beta cells of animals on the high-energy diet developed signs of cell organelle disintegration (Fig. 2), such as destroyed mitochondria or cisternae of the rough endoplasmic reticulum, culminating in necrotic cell destruction [14].

A small number of macrophages residing in and around the islets apparently act as unspecific resident and scavenger immune cells, removing cell debris from destroyed cells in diabetic islets damaged through high-energy diet feeding, as visible already at the light microcopy level (Fig. 1d-i).

An ultrastructural analysis of these scavenger macrophages in the pancreas of control and diabetic Psammomys obesus on a high-energy diet revealed no signs of activation. Figure 2 shows typical macrophages in the capillary system of an islet from a diabetic Psammomys obesus after 1 week on the high-energy diet. These macrophages reside in the capillary system of an islet. They do not migrate through the capillary endothelium into the islets between the beta cells and thus also do not engulf dying beta cells, which would be typically expected when beta cells die via apoptosis. However, as beta cells in the diabetic Psammomys obesus pancreas typically die via necrosis [14], the lack of apoptotic bodies inside the macrophages is not really surprising. In the case of necrotic beta cell death, as prevalent in diabetic Psammomys obesus pancreas, debris from dead cells is so small that it is not visible after being taken up into the cytoplasm of the macrophages (Fig. 2).

Also in the islets of diabetic Psammomys obesus no signs of macrophage activation were seen. As depicted in Fig. 2, there were no changes in the ratio of cytoplasm : nucleus in these macrophages, no enlargement and no dilatation of the endoplasmic reticulum, and no increase in the number of small vesicles.

Immunogold staining for insulin and IL- $1 \beta$ in pancreatic islets as compared with pancreas-draining lymph nodes from Psammomys obesus

In pancreatic beta cells of a diabetic Psammomys obesus fed a high-energy diet for 1 week immunogold staining for 


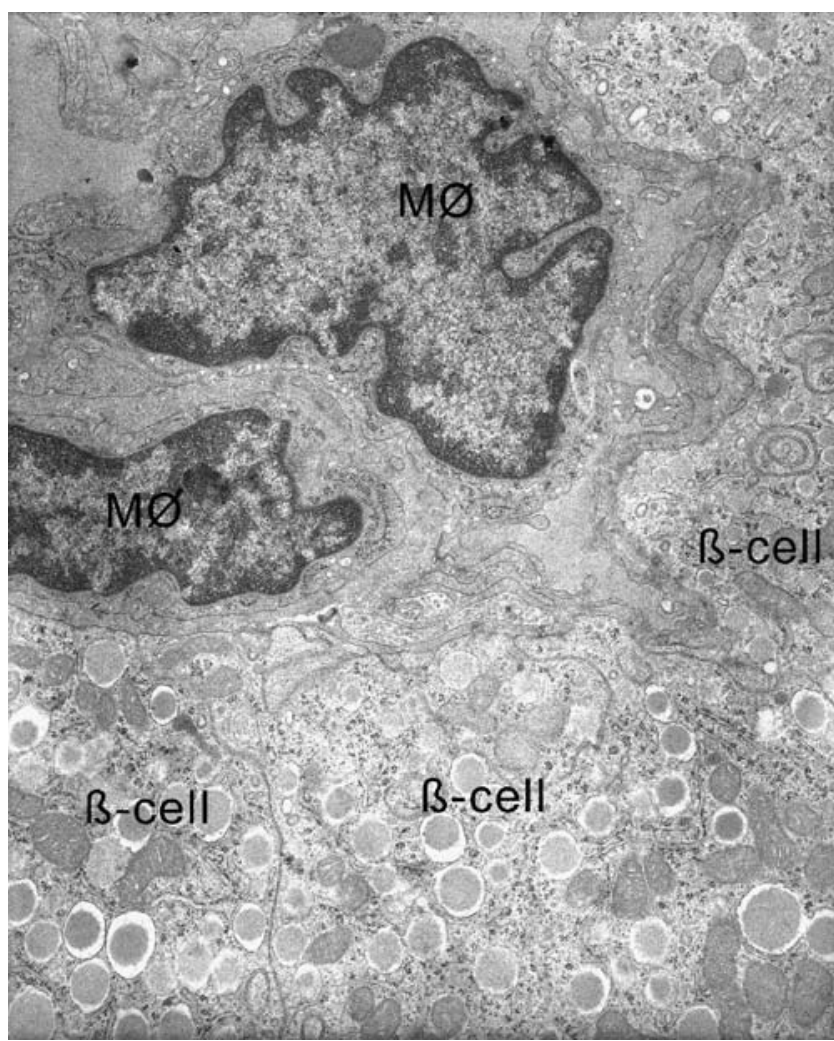

Fig. 2 Ultrastructure of a pancreatic islet from a diabetic Psammomys obesus (blood glucose $15.7 \mathrm{mmol} / \mathrm{l}$ ) after 1 week on a high-energy diet. Pancreatic beta cells $(\beta$-cell $)$ are well preserved but with signs of degranulation. Two macrophages $(M \varnothing)$ are present in the capillary system of the islet

insulin revealed localisation of the gold particles typically in the core region of the secretory granules and in the cisternae of the rough endoplasmic reticulum (Fig. 3a). On the other hand such pancreatic beta cells were completely devoid of IL-1 $\beta$ immunostaining (Fig. 3b).

In contrast and for comparison, immune cells in a pancreas-draining lymph node of a Psammomys obesus showed no expression for insulin (Fig. 3c). However, using IL-1 $\beta$ antibody, immunogold particles were found in these immune cells (Fig. 3d).

\section{Discussion}

The hypothesis that proinflammatory cytokines may be involved in the aetiopathology of type 2 diabetes mellitus originally based upon selective immunostaining results of IL-1 $\beta$ in pancreatic beta cells from a diabetic Psammomys obesus $(13.6 \mathrm{mmol} / 1$ glucose) after 1 week on a high-energy diet $[8,9]$. IL- $1 \beta$ protein expression was detected with a rodent-specific antibody $[8,9]$. Gerbil-specific antibodies are not commercially available.
Using rodent-specific antibodies, we also were unable to detect immunohistochemical staining for IL- $1 \beta$ or for the IL-1 $\beta$-inducible enzyme iNOS, either in the pancreatic beta cells or in the small number of immune cells, mostly macrophages and a few neutrophils, which can be observed in the islets of Psammomys obesus after high-energy diet feeding $[12,16]$. In contrast, all types of immune cells clearly stained positive immunohistochemically in lymph nodes and spleen [12]. This lack of immunohistochemical staining for IL-1 $\beta$ and for iNOS is in sharp contrast to infiltrated islets from a type 1 diabetes animal model, the LEW-1AR1-iddm rat, which we used in parallel analyses as a positive control. In these infiltrated type 1 diabetes islets the immune cells showed a dense immunostaining for IL$1 \beta$ and iNOS $[12,16]$. To exclude the possibility that low contents of IL-1 $\beta$ and iNOS could have been masked by fixation in the immunohistochemical staining procedure, we used both $4 \%$ paraformaldehyde fixed pancreatic tissue $[12,16]$, as used by Donath and collaborators [6], and cryostat sections of unfixed pancreas tissue of Psammomys obesus. Using both methods, IL-1 $\beta$ and iNOS were immunohistochemically undetectable. Thus, and in contrast to Donath and collaborators $[6,8,9]$, we were unable to find any evidence for hyperglycaemia-induced IL-1 $\beta$ or iNOS immunostaining at the protein level, either in pancreatic beta cells or in immune cells in the Psammomys pancreas [12]. As we analysed islets from gerbils that had been on a high-energy diet both for 1 and for 3 weeks, we can also exclude a transient increase in expression of IL-1 $\beta$. However, we cannot rule out the possibility that a microvacuolisation in the cytoplasm of damaged beta cells may have caused a positive IL- $1 \beta$ immunostaining through retention of IL-1 $\beta$ antibody in the cytoplasm in the studies by Maedler and collaborators [9]. As we used gerbils from the same colony as these authors [9], this cannot explain our inability to observe an involvement of IL-1 $\beta$ in the disease process in this type 2 diabetes model.

Immunogold staining for insulin and IL- $1 \beta$ in pancreatic islets at the electron microscopical level, as performed in the present study, also failed to show evidence for IL-1 $\beta$ staining, both in the pancreatic beta cells and immune cells, whereas immune cells in the pancreas-draining lymph node, used as a positive control, revealed clear IL-1 $\beta$ immunostaining. These immunogold staining results provide additional independent evidence for a lack of IL- $1 \beta$ protein expression in beta cells and immune cells in the Psammomys obesus islets. Furthermore, these results in no way support the recently proposed co-localisation between IL$1 \beta$ and insulin in secretory granules of beta cells from islets exposed to supraphysiological glucose concentrations (33 mmol/l) [6].

Surprised by these apparently conflicting results between our own work, both here and elsewhere [12], and the 
Fig. 3 Immunogold staining for insulin and IL-1 $\beta$ in pancreatic beta cells of a diabetic Psammomys obesus (blood glucose $15.7 \mathrm{mmol} / \mathrm{l}$ ) after 1 week on a high-energy diet and in immune cells of a pancreas-draining lymph node. After insulin staining, immunogold particles were detected as black dots in the core regions of secretory granules in pancreatic beta cells (a), but were completely absent in the cytoplasm of the immune cells (b). After IL-1 $\beta$ immunostaining, immunogold particles were detected as black dots in the cytoplasm of the immune cells (d), but not in pancreatic beta cells (c)
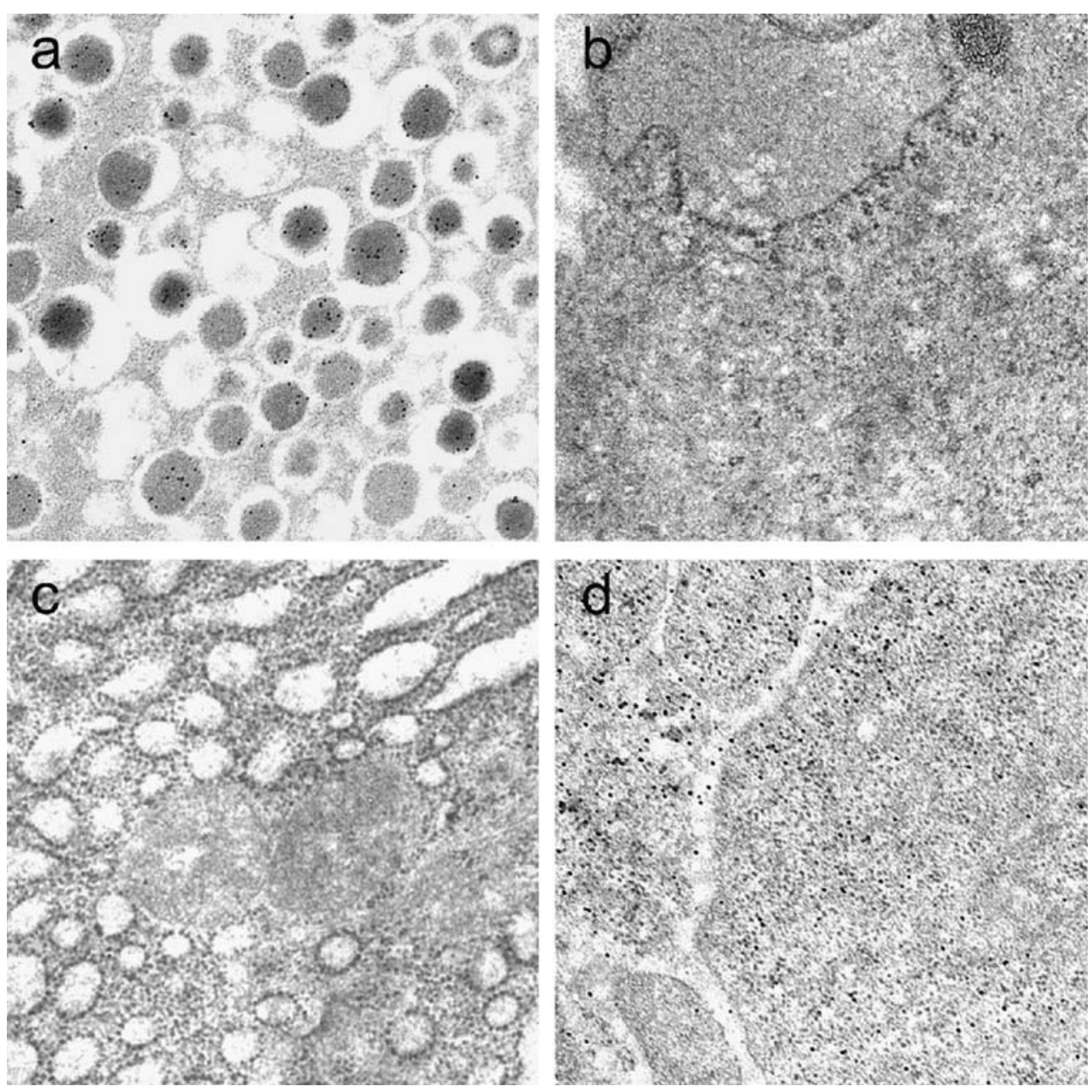

observations by Donath and co-workers $[6,8,9]$, we decided to use a novel and complementary approach to address the issue of a possible participation of proinflammatory cytokines in the aetiopathology of beta cell damage in type 2 diabetes mellitus. To overcome the fact that gerbil-specific antibodies are not available, we performed in situ RT-PCR and real-time RT-PCR studies, using for the first time gerbil-specific primers. Thus, expression of the genes encoding IL-1 $\beta$ and other proinflammatory cytokines, namely TNF- $\alpha$ and IFN- $\gamma$, as well as the IL- $1 \beta$ regulated enzyme iNOS, was analysed in pancreatic islets from normoglycaemic and diabetic Psammomys obesus using gerbil-specific primers. In beta cells and other islet cell types, as well as in the acinar and duct tissue of pancreas sections from $P$. obesus, none of the mRNAs of these four cytokines was detectable by in situ RT-PCR. Similarly, an analysis of the small number of immune cells in islets both from control and diabetic P. obesus revealed no expression of any of the mRNAs for these four proteins. These immune cells in the islets from the control gerbil, and in particular from diabetic animals, did not show any signs of activation during electron microscopical examination, such as an increase of the rough endoplasmic reticulum and the number of small vesicles, thus providing additional independent evidence for the inactivity of the intraislet immune cells.

These findings confirm the existence of immunologically inactive scavenger macrophages inside pancreatic islets, whose function is probably the removal of cell debris from dead cells that die during the normal cell cycle [20].

With real-time RT-PCR, Il-1 $\beta$ and iNos were detected at similar levels both in collagenase-isolated islets and in laser-microdissected islets from the pancreas of normoglycaemic and hyperglycaemic animals. They were present, however, at a very low level, with cycle threshold values between 32 and 33, while expression levels of Tnf- $\alpha$ and If $n-\gamma$ were very close to the detection limit, with cycle threshold values at least another two decimal powers lower than for $I l-1 \beta$. On the other hand, immune cells of lymphoid tissues from Psammomys obesus, namely pancreas-draining lymph nodes and spleen, expressed all three 
proinflammatory cytokines, as well as iNOS, at high levels, comparable to those typically found in infiltrated islets of type 1 diabetes animal models [21,22]. While the source of the high level expression of cytokines in type 1 diabetes infiltrated islets is clearly the infiltrating immune cells [16, 23], it is likely that this low level of mRNA in P. obesus islets represents expression of the genes encoding cytokines in beta cells, like that also observed in human [13] and rat [24] pancreatic beta cells. Importantly, in the present and previous studies [13], this minute expression of $I l-1 \beta$ was not augmented by high glucose. At variance with the situation in type 1 diabetes mellitus [12], beta cell death in $P$. obesus fed a high-carbohydrate diet has been shown to be predominantly the result of necrosis [14], a conclusion supported by more recent publications $[6,25,26]$. This necrotic beta cell death, which consists of destruction of the rough endoplasmic reticulum, can also explain the reduced expression of $I l-1 \beta$ and $i N o s$ in beta cells from diabetic animals.

Our study, using gerbil-specific primers, excludes the possibility that differences in the gene sequences of $\mathrm{Il}-1 \beta$ and other cytokines, as well as of iNos between gerbil and other rodents such as the rat could be a potential reason for false positive results. Rat primers are not suited for detection of gene expression in gerbil tissues (unpublished observation, A. Jörns, Hanover, Germany). Thus our results do not provide a rationale for prevention studies using IL$1 \beta$ antibodies [5] in humans with type 2 diabetes mellitus. On the other hand, type 2 diabetes mellitus is a heterogeneous disease and it cannot be ruled out that an inflammatory background represents a component of the disease process in some patients $[27,28]$.

The results of the present PCR gene expression analyses with gerbil-specific primers therefore confirm the results obtained by immunohistochemistry [12] and the present immunogold analyses, and in particular confirm the lack of any hyperglycaemia-induced increase in expression of the genes encoding the cytokines studied and iNOS in Psammomys obesus. The low gene expression levels observed by real-time RT-PCR in Psammomys islets are also in agreement with the low level of expression of $I l-1 \beta$ and iNos as found in human [13] and rat [24] pancreatic beta cells by real-time RT-PCR.

Thus it can be concluded that the diabetic syndrome induced by a high-energy diet in Psammomys obesus resembles a classical type 2 diabetes mellitus syndrome without any evidence for involvement of the proinflammatory cytokine IL- $1 \beta$ in its pathogenesis, or any evidence for involvement of activated immune cells in the process of beta cell damage and loss in the pathogenesis of type 2 diabetes mellitus in this gerbil.

This is clearly at variance with the situation in type 1 diabetes animal models $[2,12,16]$, where not only IL-1 $\beta$, but also other proinflammatory cytokines play a pivotal role in the disease process.

Acknowledgements The technical assistance of D. Lischke and U. Sommerfeld is gratefully acknowledged. This work was supported by grants from the Deutsche Forschungsgemeinschaft and the European Union (Integrated Project EuroDia LSHM-CT2006-518153 in the Framework Programme 6 of the EuropeanUnion).

\section{References}

1. Eizirik DL, Mandrup-Poulsen T (2001) A choice of death the signal-transduction of immune-mediated beta-cell apoptosis. Diabetologia 44:2115-2133

2. Lally FJ, Bone AJ (2002) Animal models of type 1 diabetes. In: Pickup JC, Williams G (eds) Textbook of Diabetes. Blackwell Scientific, Oxford, pp 19.11-19.17

3. Eisenbarth GS (2005) Type I diabetes. Molecular, cellular and clinical immunology. Oxford University Press, Oxford

4. Donath MY, Storling J, Maedler K, Mandrup-Poulsen T (2003) Inflammatory mediators and islet beta-cell failure: a link between type 1 and type 2 diabetes. J Mol Med 81:455-470

5. Donath MY, Halban PA (2004) Decreased beta-cell mass in diabetes: significance, mechanisms and therapeutic implications. Diabetologia 47:581-589

6. Donath MY, Ehses JA, Maedler K et al (2005) Mechanisms of beta-cell death in type 2 diabetes. Diabetes 54(Suppl 2):S108 S113

7. Kolb H, Mandrup-Poulsen T (2005) An immune origin of type 2 diabetes? Diabetologia 48:1038-1050

8. Donath MY, Gross DJ, Cerasi E, Kaiser N (1999) Hyperglycemia-induced beta-cell apoptosis in pancreatic islets of Psammomys obesus during development of diabetes. Diabetes 48:738-744

9. Maedler K, Sergeev P, Ris F et al (2002) Glucose-induced beta cell production of IL-1beta contributes to glucotoxicity in human pancreatic islets. J Clin Invest 110:851-860

10. Shafrir E, Gutman A (1993) Psammomys obesus of the Jerusalem colony: a model for nutritionally induced, non-insulin-dependent diabetes. J Basic Clin Physiol Pharmacol 4:83-99

11. Shafrir E, Ziv E, Kalman R (2006) Nutritionally induced diabetes in desert rodents as models of type 2 diabetes: Acomys cahirinus (spiny mice) and Psammomys obesus (desert gerbil). ILAR J 47:212-224

12. Cnop M, Welsh N, Jonas JC, Jörns A, Lenzen S, Eizirik DL (2005) Mechanisms of pancreatic beta-cell death in type 1 and type 2 diabetes: many differences, few similarities. Diabetes 54 (Suppl 2):S97-S107

13. Welsh N, Cnop M, Kharroubi I et al (2005) Is there a role for locally produced interleukin-1 in the deleterious effects of high glucose or the type 2 diabetes milieu to human pancreatic islets? Diabetes 54:3238-3244

14. Jörns A, Tiedge M, Ziv E, Shafrir E, Lenzen S (2002) Gradual loss of pancreatic beta-cell insulin, glucokinase and GLUT2 glucose transporter immunoreactivities during the time course of nutritionally induced type-2 diabetes in Psammomys obesus (sand rat). Virchows Arch 440:63-69

15. Lenzen S, Tiedge M, Elsner $M$ et al (2001) The LEW.1AR1/ Ztm-iddm rat: a new model of spontaneous insulin-dependent diabetes mellitus. Diabetologia 44:1189-1196

16. Jörns A, Günther A, Hedrich HJ, Wedekind D, Tiedge M, Lenzen S (2005) Immune cell infiltration, cytokine expression, and betacell apoptosis during the development of type 1 diabetes in the 
spontaneously diabetic LEW.1AR1/Ztm-iddm rat. Diabetes 54: 2041-2052

17. Schutze K, Lahr G (1998) Identification of expressed genes by laser-mediated manipulation of single cells. Nat Biotechnol 16: 737-742

18. Bock O, Schlue J, Mengel M, Busche G, Serinsoz E, Kreipe H (2004) Thrombopoietin receptor (Mpl) expression by megakaryocytes in myeloproliferative disorders. J Pathol 203:609-615

19. Souza KL, Elsner M, Mathias PC, Lenzen S, Tiedge M (2004) Cytokines activate genes of the endocytotic pathway in insulinproducing RINm5F cells. Diabetologia 47:1292-1302

20. Arnush M, Scarim AL, Heitmeier MR, Kelly CB, Corbett JA (1998) Potential role of resident islet macrophage activation in the initiation of autoimmune diabetes. J Immunol 160:2684-2691

21. Hirai H, Kaino Y, Ito T, Kida K (2000) Analysis of cytokine mRNA expression in pancreatic islets of nonobese diabetic mice. J Pediatr Endocrinol Metab 13:91-98

22. Rabinovitch A, Suarez-Pinzon WL (1998) Cytokines and their roles in pancreatic islet beta-cell destruction and insulin-dependent diabetes mellitus. Biochem Pharmacol 55:1139-1149
23. Jörns A, Kubat B, Tiedge $M$ et al (2004) Pathology of the pancreas and other organs in the diabetic LEW.1AR1/Ztm-iddm rat, a new model of spontaneous insulin-dependent diabetes mellitus. Virchows Arch 444:183-189

24. Elouil H, Cardozo AK, Eizirik DL, Henquin JC, Jonas JC (2005) High glucose and hydrogen peroxide increase c-Myc and haemeoxygenase $1 \mathrm{mRNA}$ levels in rat pancreatic islets without activating NFkappaB. Diabetologia 48:496-505

25. Kaiser N, Yuli M, Uckaya G et al (2005) Dynamic changes in beta-cell mass and pancreatic insulin during the evolution of nutrition-dependent diabetes in Psammomys obesus: impact of glycemic control. Diabetes 54:138-145

26. Kaiser N, Nesher R, Donath MY et al (2005) Psammomys obesus, a model for environment-gene interactions in type 2 diabetes. Diabetes 54(Suppl 2):S137-S144

27. Rathcke CN, Johansen JS, Vestergaard H (2006) YKL-40, a biomarker of inflammation, is elevated in patients with type 2 diabetes and is related to insulin resistance. Inflamm Res 55:53-59

28. Pickup JC (2006) Inflammatory markers and type 2 diabetes. Diabetes Technol Ther 8:1-6 